\title{
NOVEL FACTS IN PHARMACOLOGY OF ENDOTHELIAL DYSFUNCTION
}

\section{NOVA SAZNANJA U FARMAKOLOGIJI ENDOTELNE DISFUNKCIJE}

\author{
Miroslav Radenković', Marko Stojanović', Milica Prostran¹
}

\section{Summary}

Homeostasis of different blood vessels is directly linked with physiological and pathological features of morphological and functional integrity of vascular endothelial cells. Vascular endothelium has a central role in the modulation of vascular tone, together with established local antioxidant, anti - inflammatory, profibrinolytic, anti - adhesive and anticoagulant activity. These effects are results of timely production and release of vasoactive autacoids, where nitric oxide, prostacyclin and endothelially - derived hyperpolarizing factor are considered to be crucial for physiological cellular signaling mechanisms. In contrast, endothelial dysfunction is a pathological process, which is known to be correlated with different vascular pathological conditions. It is basically characterized by marked disturbance of the regulation of vascular tone, as a consequence of reduced bioavailability of endothelial relaxing factors and concomitant enhanced production of endothelial contractile factors. Moreover, endothelial cells are affected by oxidative stress and increased inflammatory processes that are all associated with migration of circulating leukocytes in subendothelial space and enhanced pathological proliferation of adjacent smooth muscle cells. Pharmacological approach in improving endothelial dysfunction currently represents a crucial part in different cardiovascular clinical trials. Conventional drugs, including statins, ACE-inhibitors, angiotensin receptor blockers, oral antidiabetic agents or some beta adrenoceptor antgonists, all have clearly established efficacy in improving endothelial function, either via direct or indirect mechanisms of action. Besides, it has been concluded that, under specific conditions, some dietary ingredients, natural products or specific dietary supplements can improve endothelial dysfunction and overall vascular homeostasis. Owing to the fact that endothelial dysfunction was confirmed to be associated with etiology and/or further progression of different vascular disturbances, clinical investigations of novel pharmacological possibilities for improving endothelial dysfunction still represents an up - to - date trend in scientifically - based attempts of discovering a viable therapeutic solutions in treating cardiovascular diseases.

Key words: endothelial dysfunction, nitric oxide, TNF-alpha, pathological angiogenesis, eNOS

\section{Sažetak}

Homeostaza krvnih sudova različitih organa i organskih sistema u direktnoj je korelaciji sa fiziološkim ili patološkim stanjem morfološkog i funkcionalnog integriteta vaskularnih endotelnih ćelija. Vaskularni endotel ima ključnu ulogu u modulaciij tonusa krvnih sudova, sa takođe potvrđenim lokalnim antioksidantnim, antiinflamatornim, profibrinolitičkim, antiadhezivnim i antikoagulantnim dejstvima. Navedeni efekti su posledica pravovremene produkcije i oslobađanja vazoaktivnih autakoida, od kojih su za fiziološke ćelijske signalne mehanizme najvažniji azot oksid, prostaciklin ili endotelni hiperpolarišući faktor. Suprotno prethodnom, endotelna disfunkcija je patološki proces, koji se dovodi u vezu sa nastankom ili napredovanjem različitih vaskularnih bolesti i koji se u osnovi odlikuje poremećajem regulacije vaskularnog tonusa kao posledica smanjene raspoloživosti endotelnih relaksantnih faktora, odnosno povećane produkcije endotelnih kontraktilnih faktora. Endotelne ćelije pokazuju prisustvo pojačanog oksidativnog stresa i inflamatornih procesa sa udruženom migracijom cirkulišućih leukocita u subentotelni sloj i patološkom stimulacijom proliferacije susednih glatkih mišićnih ćelija. Farmakološki pristup u popravljanju endotelne disfunkcije danas predstavlja veoma važan segment protokola različitih kliničkih ispitivanja u oblasti kardiovaskularne patologije. Konvencionalni lekovi, kakvi su npr. statini, ACE-inhibitori, blokatori angiotenzinskih receptora, oralni antidijabetici ili neki beta blokatori jasno pokazuju korisne efekte u popravljanju endotelne funkcije, bilo da su posledica direktnog ili indirektnog mehanizma dejstva. Pored ovoga, za specifične sastojke hrane, neke supstance prirodnog porekla ili određene dodatke ishrani je utvrđeno da pod definisanim uslovima značajno doprinose popravljanju endotelne disfunkcije i sveukupne homeostaze vaskularnog sistema. Uzimajući u obzir da je endotelna disfunkcija kao patološki proces povezana sa nastankom i/li progresijom različitih vaskularnih poremećaja, klinička istraživanja novih farmakoloških mogućnosti popravljanja endotelne disfunkcije i dalje predstavljaju veoma aktuelni trend u naučno zasnovanim pokušajima pronalaženja efikasnih terapijskih rešenja u tretmanu kardiovaskularnih bolesti.

Ključne reči: endotelna disfunkcija, azot oksid, TNF-alfa, patološka angiogeneza, eNOS 
Endotelna disfunkcija predstavlja inicijalni korak u patogenezi ateroskleroze i u svojoj osnovi se karakteriše smanjenom produkcijom endotelnih relaksantnih faktora (uglavnom azot oksida) i/ili povećanim oslobađanjem endotelnih kontraktilnih faktora $(15,31)$. Pored ovoga, aktivacija nikotinamid-adenin dinukleotid fosfat oksidaze, ksantin oksidaze, ciklooksigenaze i elektronskog transporta u mitohondrijama, zajedno sa istovremenom inaktivacijom intracelularnog antioksidacionog sistema i redukovanom aktivacijom endotelne NO-sintaze prouzrokuje oksidativni stres, praćenim povećanom produkcijom i smanjenom razgradnjom slobodnih kiseonikovih radikala (18). Faktori i mehanizmi koji modulišu balans između fiziološkog oslobađanja relaksantnih, antikoagulantnih, antiagregacionih $\mathrm{i}$ antimitotičkih faktora iz endotelnih ćelija sa jedne strane, $u$ odnosu na kontraktilne, proagregacione i promitotičke faktore vezane za gubitak protektivne funkcije endotela sa druge strane, još uvek nisu u potpunosti razjašnjeni (2). Stoga se ovaj kompleksni i sistemski patološki poremećaj može posmatrati i klasifikovati sa etiološkog, funkcionalnog i prognostičkog aspekta (10).

Uzimajući u obzir ozbiljne zdravstvene sekvele povezane sa patološkom aktivacijom i poremećajem funkcije endotelnih ćelija, metodološki postupci i biomarkeri za kliničku procenu endotelne disfunkcije svakim danom su sve brojniji $(16,38)$. Ovo je posledica danas prihvaćenog konsenzusa da ne postoji uvek vidljiva i direktna korelacija između različitih terapijskih opcija i popravljanja endotelne disfunkcije, već da se radi o kompleksnim transdukcionim procesima i vezama između brojnih celularnih i subcelularnih ciljnih mesta vezivanja farmakološki aktivnih supstanci (39). Ovo se poklapa sa dosadašnjim nalazima da postignuto poboljšanje endotelne disfunkcije primenom određenih lekova nije uvek i održivo, niti da uvek postoji jasna korelacija između krajnjeg kliničkog ishoda primenjene terapije i reverzije endotelne disfunkcije. Smatra se da je jedan od uzroka za ovakve kliničke nedoumice još uvek nedovoljno poznavanja pleiotropnih mehanizama dejstva lekova za koje je pokazano da popravljaju endotelnu disfunkciju, kakvi su npr. statini, ACE inhibitori, blokatori angiotenzinskih AT1 receptora ili tiazolidindioni, ali i drugih farmakološki aktivnih supstanci čiji se mehanizmi dejstva u ovoj oblasti još uvek ispituju (21, 30,31). Stoga će u ovom prikazu u kratkim crtama biti predstavljena neka od najnovija saznanja i usmerenja vezana za potencijalne farmakološke mogućnosti u popravljanju endotelne disfunkcije.

\section{ENDOTELNA DISFUNKCIJA I INFLAMATORNI CITOKINI}

Sve je više dokaza koji ukazuju na povezanost hroničnih autoimunih inflamatornih bolesti sa ubrzanim pro- cesom razvoja ateroskleroze, kao i generalno povećanim kardiovaskularnim morbiditetom i mortalitetom $(24,29)$. Ovo je posledica brojnih nalaza u kojima se nastanak i progresija ateroskleroze sve više posmatra kao inflamatorni proces i dovodi u direktnu korelaciju sa patogenetskim mehanizmima prepoznatim kao važnim za napredovanje hroničnih autoimunih inflamatornih bolesti. Iako je u ovom kontekstu reumatoidni artritis najviše proučavan, sve je veći broj pozitivnih pokazatelja za povećani kardiovaskularni rizik kod pacijenata sa sistemskim lupusom eritematozusom, seronegativnim spondiloartropatijama, psorijazom i zapaljenskom bolešću debelog creva $(3,22,26,34)$. Sa tim u vezi, endotelna disfunkcija se kod pacijenata sa hroničnim inflamatornim bolestima često može identifikovati u ranim fazama razvoja bolesti. Stoga se danas smatra da se mehanizmi koji povezuju sistemska inflamatorna oboljenja i aterosklerozu možda ponajbolje mogu razumeti upravo na nivou endotelnih ćelija.

Pojačana produkcija TNF-alfa (tumor necrosis factor-alpha) i drugih inflamatornih citokina direktno doprinosi razvoju endotelne disfunkcije i posledičnoj aterosklerozi. Naime, utvrđeno je da TNF-alfa indukuje povećanu ekspresiju adhezionih molekula sa sledstvenim privlačenjem cirkulišućih imunih ćelija prema ateromatoznom plaku, smanjuje biološku raspoloživost endotelne NO-sintaze, pojačava oksidacioni stres i apoptozu endotelnih ćelija, kao i da negativno utiče na funkciju i broj endotelnih progenitornih ćelija (3, 11). Sa druge strane, za inhibitore TNF-alfa je pokazano da redukuju serumski nivo ne samo TNF-alfa, već $i$ drugih markera inflamacije, kao što su npr. C-reaktivni protein (CRP) ili IL-6, ali isto tako i da stimulišu povećanu ekspresiju endotelne NO-sintaze (25). Stoga se u ovom trenutku sa velikom sigurnošću pretpostavlja da bi farmakološki aktivne supstance usmerene protiv inflamatornog dejstva TNF-alfa (infliksimab, etanercept, adalimumab) mogle u značajnoj meri redukovati rizik za nastanak endotelne disfunkcije i pridruženih kardiovaskularnih oboljenja kod pacijenata sa hroničnim sistemskim inflamatornim bolestima (37).

\section{ENDOTELNA DISFUNKCIJA I POVEĆANA MIKROVASKULARNA PROPUSTLJIVOST}

Rezultati istraživanja skorijeg datuma ukazuju na direktnu povezanost poremećaja mehaničke funkcije endotelnog sloja ćelija i povećane mikrovaskularne propustljivosti sa patogenezom disfunkcije različitih organa prouzrokovanom infektivnim agensima. Tako je pokazano da povećana mikrovaskularna propustljivost izazvana kompromitovanom mehaničkom funkcijom endotelne barijere ima važnu ulogu u patogenezi i progresiji brojnih infektivnih sindroma uključujući 
sepsu, akutnu povredu pluća, denga hemoragijsku groznicu, hemoragijske groznice virusnog porekla ili npr. plućni sindrom povezan sa hantavirus infekcijom (5, $12,23,27,33)$. U fiziološkim uslovima polupropustljivi sloj endotelnih ćelija omogućava ograničeni prenos različitih materija iz krvi prema tkivu zida krvnog suda. Međutim, u patološkim uslovima nekontrolisana permeabilnost endotelnog sloja rezultuje povećanom propustljivošću za molekule proteina i vode, što dovodi do stvaranja paracelularnog edema. Smatra se da je ovaj proces delimično stimulisan postojanjem infektivnog procesa u organizmu. Stoga se pretpostavlja da bi jedan od mogućih novih pravaca u popravljanju endotelne disfukcije mogao biti usmeren na osmišljavanje terapijskih strategija za ograničavanje propustljivosti endotelnog sloja ćelija prouzrokovanog infektivnim agensima, čime bi se poboljšala prevencija, a u isto vreme redukovala dalja oštećenja i gubitak funkcije različitih organa.

Uzimajući u obzir činjenicu da se radi o relativno novijem pristupu u popravljanju funkcije endotela, rezultati iz ove naučne oblasti predominantno dolaze iz prekliničkih istraživanja u kojima su korišćeni različiti modeli infektivnih bolesti. Karakterizacija farmakološki aktivnih supstanci sa izraženim potencijalom za ojačavanje endotelnog sloja ćelija kao mehaničke barijere danas predstavlja izuzetno atraktivno polje istraživanja, a među ispitivanim supstancama i lekovima svakako treba pomenuti antagoniste tipa 2 vaskularnog endotelnog faktora rasta (VEGFR2/Src), agoniste sfingozin-1-fosfata, fibrinopeptid $\mathrm{Bb}$, slit2 $\mathrm{N}$, secin $\mathrm{H} 3$, agoniste angiopoetin-1/Tie2, antagoniste angiopoetina-2, statine, atrijalni natriuretski peptid, kao i mezenhimalne stromalne (stem) ćelije (4). S obzirom na to da različite virusne infekcije mogu prouzrokovati poremećaj funkcije endotelnih ćelija, terapijske opcije usmerene prema endotelu kao ciljnom mestu dejstva, potencijalno mogu imati široki opseg upotrebe u prevenciji i dopunskom tretmanu virusnih infekcija, a time i ograničavanju oštećenja ciljnih tkiva i organa. Ipak, uzimajući u obzir brojna ograničenja eksperimentalnih modela neophodno je sprovođenje adekvatno dizajniranih kliničkih studija sa ciljem utvrđivanja da li strategija stabilizacije vaskularnog endotela zaista može biti efikasna u redukovanju morbiditeta i mortaliteta povezanih sa endotelnom disfunkcijom uzrokovanom infektivnim procesom.

\section{ENDOTELNA DISFUNKCIJA I PATOLOŠKA ANGIOGENEZA}

Patološko formiranje novih krvnih sudova (patološka angiogeneza) i endotelna disfunkcija karakterišu brojna oboljenja. Na osnovu nedavnih naučnih nalaza postojanja pozitivne povezanosti patološke angiogeneze i endotelne disfunkcije sa specifičnim metaboličkim poremećajima identifikovanim u endotelnim ćelijama (i to posebno onima vezanim za metabolizam gluko- ze), može se pretpostaviti da bi popravljanje ili reverzija metaboličkih alteracija u endotelnim ćelijama mogao biti jedan od novih terapijskih pravaca u poboljšanju različitih parametara endotelne disfunkcije (14). Ovo je u saglasnosti sa činjenicom da brojni faktori rizika za pojavu različitih kardiovaskularnih oboljenja (hiperholesterolemija, hipertenzija, dislipidemija, dijabetes, gojaznost, starenje) dovode do specifičnih metaboličkih alteracija u endotelnim ćelijama i na posletku do endotelne disfunkcije $(6,28)$. Takođe je pokazana i povezanost promena u metabolizmu endotelnih ćelija i patološke angiogeneze, a sa tim u vezi i patološke migracije i proliferacije endotelnih ćelija u tkiva sa smanjenom perfuzijom i oksigenacijom, tj. u tkiva sa patološkim poremećajem metaboličkih signalnih mehanizama (17).

Uzimajući u obzir značaj i sveukupni doprinos promena metabolizma glukoze u endotelnim ćelijama u odnosu na endotelnu disfunkciju i patološku angiogenezu, nedavno je pokazano da farmakološka inhibicija glikolitičkog enzima 6-fosfofrukto-2-kinaza/fruktoza-2,6-bifosfataze-3 (PFKFB3) prouzrokuje inhibiciju patološke angiogeneze, što bi moglo predstavljati jedan od značajnih pomaka terapijskom pristupu poboljšanja vaskularne funkcije u različitim patološkim stanjima ( 7 , $32,42)$. Ovome doprinosi i nalaz da parcijalna i kratkotrajna redukcija glikolize antiglikolitičkom terapijom može biti dovoljna da prozrokuje adekvatnu inhibiciju patološke angiogeneze bez istovremene pojave sistemskih neželjenih efekata uzrokovanih kompletnom i trajnom blokadom ovog važnog metaboličkog procesa (14). Ipak, treba dodati da bi dalja i sveobuhvatnija karakterizacija metaboličkih puteva u endotelnim ćelijama verovatno u značajnoj meri doprinela daljem pronalaženju farmakoloških mehanizama za reverziju endotelne disfunkcije i patološke angiogeneze, s obzirom na to da se izmenjenim metaboličkim putevima u endotelnoj disfunkciji još uvek ne pridaje adekvatan značaj u sveukupnom posmatranju patofizioloških mehanizama vezanih za poremećaj fiziološke funkcije endotelnih ćelija.

\section{ENDOTELNA DISFUNKCIJA I NEPRAVILNA AKTIVACIJA ENOS}

Poznato je da se u vaskularnom endotelu azot oksid, kao ključni endotelni relaksantni faktor stvara u hemijskoj reakciji katalitički regulisanoj dejstvom endotelne NO-sintaze (eNOS), sa L-argininom kao osnovnim supstratom, kao i flavin adenin dinukleotidom (FAD), flavin mononukleotidom (FMN) i tetrahidrobiopterinom (BH4), kao neophodnim kofaktorima za adekvatno funkcionisanje NO-sintaze (9). Suprotno, u nedostatku L-arginina ili tetrahidrobiopterina ne dolazi do pravilne aktivacije NO-sintaze, usled čega ovaj enzim pojačano katalizuje reakcije stvaranja slobodnih kiseonikovih radikala. Ovo predstavlja jedan od važnijih mehanizama nastanka endotelne disfunkcije (31). Sa tim u vezi, argi- 
naza kao esencijalni enzim u metabolizmu ureje takođe koristi L-arginin kao svoj supstrat i na taj način se može nalaziti u direktnoj kompeticiji sa endotelnom NO-sintazom, što sve može prouzrokovati smanjenu aktivaciju ovog enzima i preusmeravanje signalne kaskade ka povećanoj produkciji slobodnih kiseonikovih radikala u endotelnim ćelijama $(1,36,41)$. Iako je danas potvrđeno da postoje dve izoforme arginaze, predominantna izoforma u humanim endotelnim ćelijama je arginaza II.

Povećana ekspersija i aktivnost arginaze zabeležena je u mnogim patološkim stanjima, kao što su hipertenzija, ateroskleroza, diabetes mellitus ili npr. u ishemijsko-reperfuzijskim oštećenjima srčanog mišića, pluća i bubrega (35). Pored ovoga, aktivnost arginaze može biti indukovana dejstvom lipopolisaharida, TNF-alfa, interferonom-gama, 8-bromo-cGMP ili hipoksijom. Iako je koncept razvoja specifičnih i potentnih inhibitora arginaze $u$ popravljanju endotelne disfunkcije prisutan već određeni niz godina, najnovija saznanja iz ove oblasti ukazuju da bi farmakološki aktivne supstance sa opisanim dejstvom mogle biti od značaja u smanjenju oksidativnog stresa i pomeranju biohemijskih signalnih mehanizama sa patološke produkcije slobodnih kiseonikovih radikala prema povećanoj sintezi endotelnog azot oksida. Među ovim supstancama trebalo bi izdvojiti piceatanol-3'-O-beta-Dglukopiranozid, flavanoide izolovane iz biljke Scutellaria indica ili npr. 2-amino-6-boronoheksanoične kiseline (8, $13,20,40)$. Ovo bi sve moglo biti od posebnog značaja u tretmanu pacijenata sa dijagnozom diabetes mellitus tipa 2, uzimajući u obzir potvrđeno pojačano dejstvo arginaze sa udruženim poremećajem aktivnosti NO-sintaze kod ovih bolesnika (19).

\section{ZAKLJUČAK}

Endotelna disfunkcija predstavlja sistemski patološki poremećaj primarno karakterisan redukovanom produkcijom i oslobađanjem azot oksida. Ona dovodi do signifikantnog poremećaja vaskularne homeostaze udružene sa gubitkom protektivnih svojstava endotelnih ćelija i posledičnog razvoja ateroskleroze, a zatim i pridruženih kardiovaskularnih bolesti. Endotelnom disfunkcijom može biti zahvaćen bilo koji deo vaskularnog sistema. Stoga se pravovremena procena endotelne funkcije danas ubraja u veoma važne pokazatelje sveukupnog stanja kardiovaskularnog sistema, kao i procene kardiovaskularnog rizika. Uzimajući u obzir važnost endotelne disfunkcije u patogenezi različitih kardiovaskularnih bolesti, razumevanje što većeg broja transdukcionih mehanizama uključenih u nastanak endotelne disfunkcije je od ključnog značaja u otkrivanju i razvoju novih farmakološki aktivnih supstanci, koje bi mogle dovesti do popravljanja poremećene funkcije endotelnih ćelija.

\section{NAPOMENA}

Rad je usmeno izložen na mini simpozijumu 90 godina Instituta za farmakologiju, kliničku farmakologiju i toksikologiju - Najnovija saznanja i kontroverze u bazičnoj i kliničkoj farmakologiji na 43. simpozijumu Stremljenja $i$ novine u medicini, Medicinski fakultet u Beogradu, 10.12.2014. godine.

\section{Literatura}

1. Berkowitz DE, White R, Li D, Minhas KM, Cernetich A, Kim S, et al. Arginase reciprocally regulates nitric oxide synthase activity and contributes to endothelial dysfunction in aging blood vessels. Circulation. 2003;108(16):2000-6.

2. Bernatova I. Endothelial dysfunction in experimental models of arterial hypertension: cause or consequence? Biomed Res Int. 2014;2014:598271.

3. Brezinski EA, Follansbee MR, Armstrong EJ, Armstrong AW. Endothelial dysfunction and the effects of TNF inhibitors on the endothelium in psoriasis and psoriatic arthritis: a systematic review. Curr Pharm Des. 2014;20(4):513-28.

4. Darwish I, Liles WC. Emerging therapeutic strategies to prevent infection-related microvascular endothelial activation and dysfunction. Virulence. 2013;4(6):572-82.

5. Dalrymple NA, Mackow ER. Endothelial cells elicit immune-enhancing responses to dengue virus infection. J Virol 2012; 86:6408-15.

6. Davignon J, Ganz P. Role of endothelial dysfunction in atherosclerosis. Circulation. 2004;109(23 Suppl 1):III27-32.

7. De Bock K, Georgiadou M, Schoors S, Kuchnio A, Wong BW, Cantelmo AR, et al. Role of PFKFB3-driven glycolysis in vessel sprouting. Cell. 2013;154(3):651-63.

8. De Vriese AS, Verbeuren TJ, Van de Voorde J, Lameire NH, Vanhoutte PM. Endothelial dysfunction in diabetes. Br J Pharmacol. 2000;130(5):963-74.

9. Eren E, Ellidag HY, Aydin O, Yilmaz N. Homocysteine, paraoxonase-1 and vascular endothelial dysfunction: Omnibus viis romam pervenitur. J Clin Diagn Res. 2014; 8(9): CE01-4.
10. Evora PR, Baldo CF, Celotto AC, Capellini VK. Endothelium dysfunction classification: why is it still an open discussion? Int J Cardiol. 2009;137(2):175-6.

11. Garg N, Syngle A, Verma I, Krishan P. Endothelial progenitor cells as cardiovascular surrogate markers in seropositive rheumatoid arthritis. IJRCI. 2015;3(1):OA1.

12. Goldenberg NM, Steinberg BE, Slutsky AS, Lee WL. Broken barriers: a new take on sepsis pathogenesis. Sci Transl Med 2011; 3:88ps25.

13. Golebiowski A, Paul Beckett R, Van Zandt M, Ji MK, Whitehouse D, Ryder TR, et al. 2-Substituted-2-amino-6-boronohexanoic acids as arginase inhibitors. Bioorg Med Chem Lett. 2013;23(7):2027-30.

14. Goveia J, Stapor P, Carmeliet P. Principles of targeting endothelial cell metabolism to treat angiogenesis and endothelial cell dysfunction in disease. EMBO Mol Med. 2014;6(9):1105-20.

15. Gutiérrez E, Flammer AJ, Lerman LO, Elízaga J, Lerman A, Francisco FA. Endothelial dysfunction over the course of coronary artery disease. Eur Heart J. 2013;34:3175-81.

16. Hamilton SJ, Watts GF. Endothelial dysfunction in diabetes: pathogen esis, significance, and treatment. Rev Diabet Stud. 2013;10(2-3):133-56.

17. Harjes U, Bensaad K, Harris AL. Endothelial cell metabolism and implications for cancer therapy. Br J Cancer. 2012;107(8):1207-12.

18. Higashi Y, Maruhashi T, Noma K, Kihara Y. Oxidative stress and endothelial dysfunction: clinical evidence and therapeutic implications. Trends Cardiovasc Med. 2014;24(4):165-9.

19. Kashyap SR, Lara A, Zhang R, Park YM, DeFronzo RA. Insulin reduces plasma arginase activity in type 2 diabetic patients. Diabetes Care. 2008;31(1):134-9. 
20. Kim SW, Cuong TD, Hung TM, Ryoo S, Lee JH, Min BS. Arginase II inhibitory activity of flavonoid compounds from Scutellaria indica. Arch Pharm Res. 2013;36(8):922-6.

21. Lin CP, Lin FY, Huang PH, Chen YL, Chen WC, Chen HY, et al. Endothelial progenitor cell dysfunction in cardiovascular diseases: role of reactive oxygen species and inflammation. Biomed Res Int. 2013;2013:845037.

22. Mathieu S, Motreff P, Soubrier M. Spondyloarthropathies: an independent cardiovascular risk factor? Jt. Bone Spine 2010; 77: 542-5.

23. Mei SH, McCarter SD, Deng Y, Parker CH, Liles WC, Stewart DJ. Prevention of LPS-induced acute lung injury in mice by mesenchymal stem cells overexpressing angiopoietin 1. PLoS Med 2007; 4:e269.

24. Murdaca G, Colombo BM, Cagnati P, Gulli R, Spanò F, Puppo F. Endothelial dysfunction in rheumatic autoimmune diseases. Atherosclerosis. 2012;224(2):309-17.

25. Murdaca G, Spanò F, Cagnati P, Puppo F. Free radicals and endothelial dysfunction: potential positive effects of TNF- $\alpha$ inhibitors. Redox Rep. 2013;18(3):95-9.

26. Nikpour M, Gladman DD, Urowitz MB. Premature coronary heart disease in systemic lupus erythematosus: What risk factors do we understand? Lupus 2013; 22: 1243-50.

27. Peters CJ, Zaki SR. Role of the endothelium in viral hemorrhagic fevers. Crit Care Med 2002; 30(Suppl):S268-73.

28. Pober JS, Min W, Bradley JR. Mechanisms of endothelial dysfunction, injury, and death. Annu Rev Pathol. 2009;4:71-95.

29. Prati C, Demougeot C, Guillot X, Godfrin-Valnet M, Wendling D. Endothelial dysfunction in joint disease. Joint Bone Spine. 2014;81(5):386-91.

30. Radenković M. Pioglitazone and Endothelial Dysfunction: Pleiotropic Effects and Possible Therapeutic Implications. Sci Pharm. 2014; 82: 709-21.

31. Radenković M, Stojanović M, Potpara T, Prostran M. Therapeutic approach in the improvement of endothelial dysfunction: the current state of the art. Biomed Res Int. 2013;2013:252158.

32. Schoors S, De Bock K, Cantelmo AR, Georgiadou M, Ghesquière B, Cauwenberghs $\mathrm{S}$, et al. Partial and transient reduction of glycolysis by PFKFB3 blockade reduces pathological angiogenesis. Cell Metab. 2014;19(1):37-48.
33. Shrivastava-Ranjan P, Rollin PE, Spiropoulou CF. Andes virus disrupts the endothelial cell barrier by induction of vascular endothelial growth factor and downregulation of VE-cadherin. J Virol 2010; 84:11227-34.

34. Singh S, Singh H, Loftus EV Jr, Pardi DS. Risk of cerebrovascular accidents and ischemic heart disease in patients with inflammatory bowel disease: A systematic review and meta-analysis. Clin Gastroenterol Hepatol. 2014; 12:382-93.

35. Steppan J, Nyhan D, Berkowitz DE. Development of novel arginase inhibitors for therapy of endothelial dysfunction. Front Immunol. 2013;4:278

36. Steppan J, Ryoo S, Schuleri KH, Gregg C, Hasan RK, White AR, et al. Arginase modulates myocardial contractility by a nitric oxide synthase 1-dependent mechanism. Proc Natl Acad Sci U S A. 2006;103(12):4759-64.

37. Steyers CM 3rd, Miller FJ Jr. Endothelial dysfunction in chronic inflammatory diseases. Int J Mol Sci. 2014;15(7):11324-49.

38. Strisciuglio T, De Luca S, Capuano E, Luciano R, Niglio T, Trimarco B, Galasso G. Endothelial dysfunction: its clinical value and methods of assessment. Curr Atheroscler Rep. 2014;16(6):417.

39. Tousoulis D, Simopoulou C, Papageorgiou N, Oikonomou E, Hatzis G, Siasos G, et al. Endothelial dysfunction in conduit arteries and in microcirculation. Novel therapeutic approaches. Pharmacol Ther. 2014 ;144(3):253-67.

40. Van Zandt MC, Whitehouse DL, Golebiowski A, Ji MK, Zhang M, Beckett RP, et al. Discovery of (R)-2-amino-6-borono-2-(2-(piperidin1-yl)ethyl)hexanoic acid and congeners as highly potent inhibitors of human arginases I and II for treatment of myocardial reperfusion injury. J Med Chem. 2013;56(6):2568-80.

41. White AR, Ryoo S, Li D, Champion HC, Steppan J, Wang D, et al. Knockdown of arginase I restores NO signaling in the vasculature of old rats. Hypertension. 2006;47(2):245-51.

42. Xu Y, An X, Guo X, Habtetsion TG, Wang Y, Xu X, et al., Endothelial PFKFB3 plays a critical role in angiogenesis. Arterioscler Thromb Vasc Biol. 2014;34(6):1231-9. 